\title{
Thermal Plasma Solution for Environmental Waste Management and Power Generation
}

\author{
F. N. C. Anyaegbunam (Ph.D.) \\ Department of Physics/Geology/Geophysics Federal University, Ndufu-Alike, Ikwo, Abakaliki.Ebonyi State.
}

\begin{abstract}
The twin problems of environmental wastes and power shortages in fast growing economies of developing countries are real. The cities are littered with municipal solid waste and other wastes in open dumps dangerous to health and environment. In addition, there is insufficient electricenergy to power the ever expanding cities and industries. One solution to these problems, which will not harm the environment, lies in the use of thermal plasma physics and associated technologies. Application of thermal Plasma to waste treatment isone of the novel methods of waste management and sustainable power generation to meet the needs of developing economies and guarantee safe environment. The thermal plasma process ensures gasification of the carbon-containing materials in the waste to produce synthesis gas (syngas) composed primarily of carbon monoxide and hydrogen, which is used to produce energy through reciprocating engine generators - gas turbines and steam boilers in integrated plasma gasification combine circle (IPGCC). Inorganic components get converted to glassy slag safe for use as a construction aggregate. The double benefits of waste treatment and energy production are realized from this plasma process. The results show the process is environmentally responsible creating a product gas with very low quantities of NOx, SOx, dioxins and furans. Thermal Plasma Processes for waste management and power generation from abundant waste is viable and sustainable.
\end{abstract}

Keyword: Plasma gasification, Environmental Waste, Power generation, Syngas

\section{Introduction}

Plasma technologies have been employed to address the environmental problems and power demands in fast growing economies, such as Nigeria [1]. Plasma is the fourth state of matter which is abundant in the universe, comprising about 99\%. Thermal Plasmas exist in astronomical bodies with temperatures in millions of degrees. Plasma is a gas in which an important fraction of the atoms is ionized when temperature is high enough to overcome ionization threshold energy $(13.6 \mathrm{eV})$, so that the electrons and ions are separately free.Plasmas are said to be quasi neutral and exhibit all sorts of collective behavior, different from neutral gases, mediated by the long distance electromagnetic forces $\mathbf{E}, \mathbf{B}$.

If $\lambda_{\mathrm{D}}$ is the Debye length, where the electron temperature is $\mathrm{T}_{\mathrm{e}}$ as the particle density, $\mathrm{n}_{\infty}$ is very large in the plasma sheath. $N_{D}$ is the Number of particles in the 'Debye Sphere', $\omega$ is the frequency of plasma oscillation and $\tau$ is the mean period between oscillations, then:

For an ionized gas to be called plasma, the following conditions must be established:

- $\lambda_{D}<<$ Size of the plasma sheath. This ensures that collective effects and quasi-neutrality are important, [1].

- $\mathrm{N}_{\mathrm{D}} \gg>1$. Particles collective effects dominate over collisions, [1].

- $\omega \tau>1$ (ensures complete plasma oscillations, [,1],[2][4], [6]).

Artificial Plasmas may also be created in the laboratory by a variety of ways, including passing a gas between two electrodes with large electrical potential differences, or by exposing gases to high temperatures. We use both mechanisms to produce thermal plasma through plasma torches used in gasification of waste, Fig. 2. The resulting ionized gas allows the formation of a plasma arc between the two electrodes, and the arc serves as a resistive heating element with the electric current creating heat which creates additional plasma that allows the arc to be sustained. A major advantage of the plasma arc as a resistive heating element is that it is formed in a gas which cannot melt or fail as can solid heating elements. Interaction between the arc and process gas introduced into the torch causes the temperature of the gas to be very high and the hot gas can exit the plasma torch at about $10,000^{\circ} \mathrm{C}$. The ability to increase the temperature of the process gas to temperatures up to ten times higher than those attainable by conventional combustion makes plasma technology ideally suited for high temperature process applications such as gasification. The presence of a non-negligible number of charge carriers makes the plasma electrically conductive so that it responds strongly to electromagnetic fields[2],[3],[4],[5].

Plasma technology application to large-scale solid waste disposal via gasification and recovery of energy from the generated gas is relatively new, [3]. As noted by [1],[2],[9], "Plasma gasification of municipal 
solid waste (MSW) is a fairly new application that combines well-established sub-systems into one new system. The sub-systems are waste processing and sorting, plasma treatment, gas cleaning, and energy production.

\section{Plasma Torch And High-Tech Plasma Process Technology}

As mentioned above, artificial Plasma is created by passing a gas between electrodes with large differences in electrical potential and by exposing the gas to high temperatures, as in the case of arc welding or graphite electrode torches. Plasma arc torches utilize a combination of these techniques [7,8,10]. The extremely intense energy produced by the plasma torch is powerful enough to disintegrate the MSW into its component elements. The systems are shown in Figs 1-3, [7].

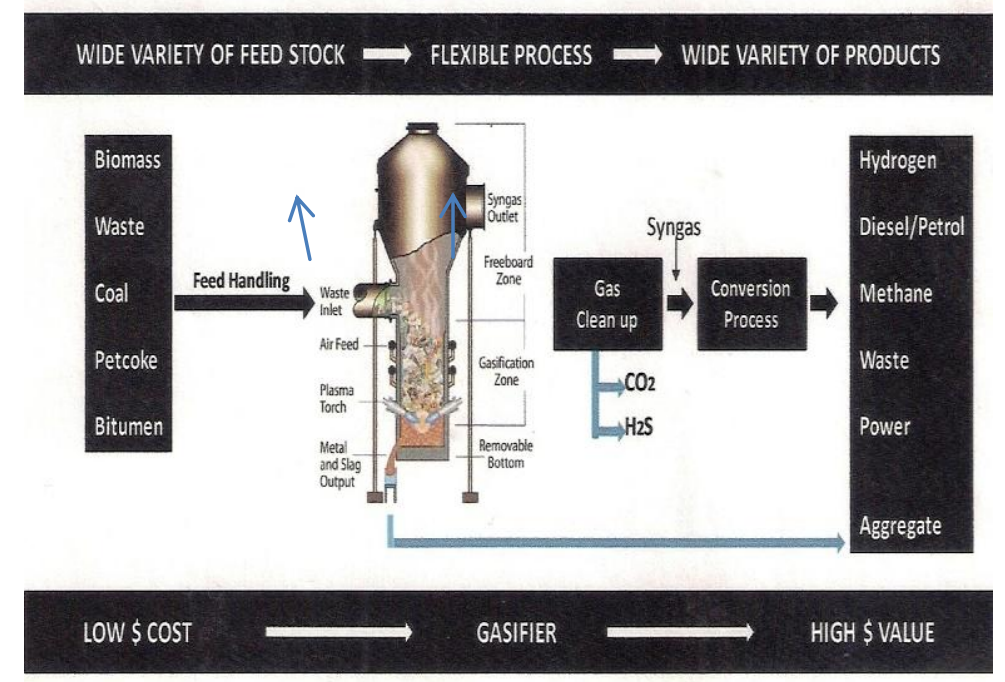

Fig. 1.Waste-Destruction \& Power-Generation (WDPG) Plasma System.

The various sub-systems include, [4],[7]:

a. Waste handling and preparation system.

b. The plasma furnace or cupola with plasma torch system.

c. The gas cooling and cleaning system to remove pollutants.

d. Various energy conversion processes.

e. Wide range of valuable products

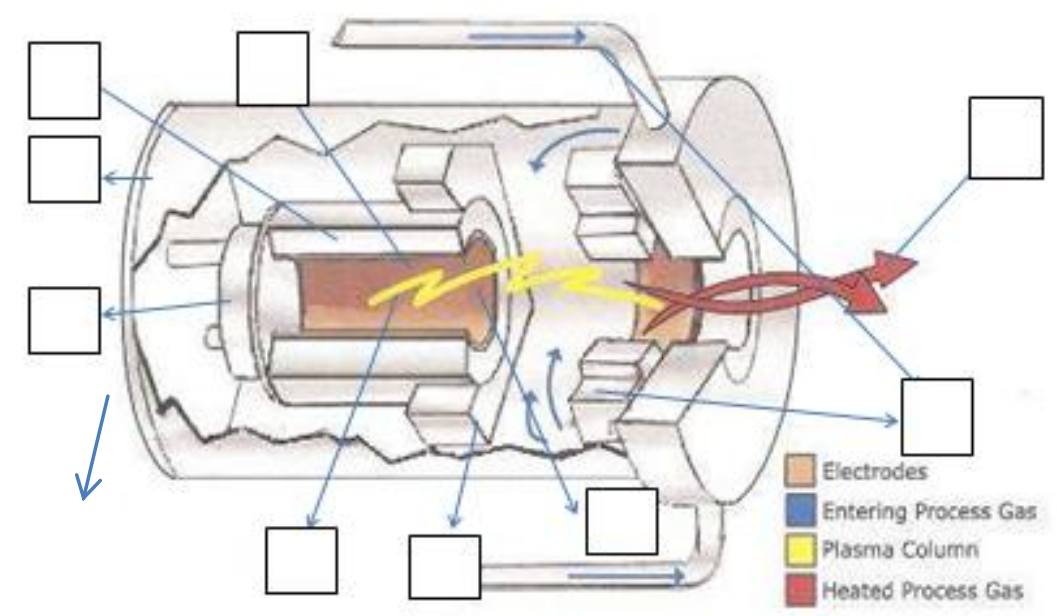

Fig. 2. Physics of Plasma Torch System 


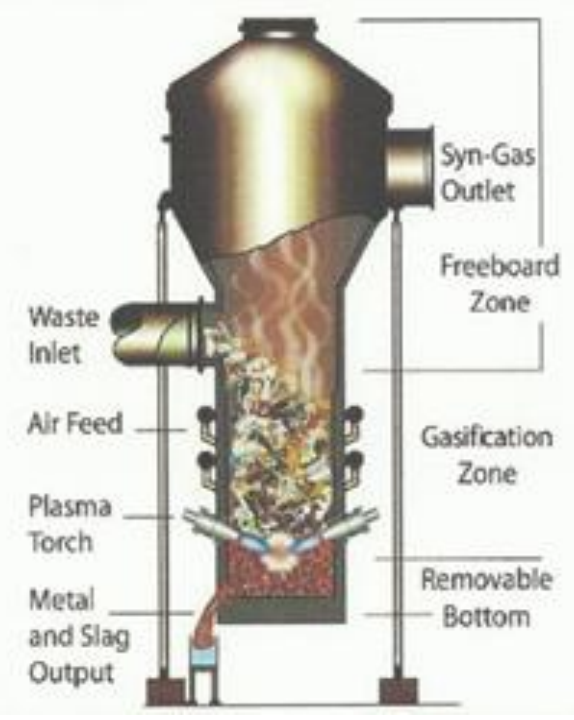

Fig. 3. Plasma Cupola

The magnetically controlled plasma torch that provides the ultra-high temperature process gas, over 10,000 degrees centigrade, which enables the feedstock of any type to be completely destroyed or gasified for the production of syngas and slag is shown in Fig. 2 which illustrates the physics of the plasma torch system [7]. The torch casing $\mathbf{1}$ is cut open to reveal the inner components. The torch is made up of two electrodes $\mathbf{3}$, cathode and anode which are connected to the power terminals $\mathbf{4}$ that provide the potential difference.

Artificial Plasma is created by passing a process gas $\mathbf{8}$, which serves as a dielectric, between electrodes $\mathbf{3}$ with large electrical potential difference. The potential difference between the electrodes $\mathbf{3}$ and subsequent electric field causes ionization of the gas and electrons are pulled toward the anode while the nucleus pulled towards cathode. The current stresses the gas by electric polarization beyond its dielectric strength into a stage of electrical breakdown. The presence of this ionized gas allows the formation of an electric arc 7 between the two electrodes. A rotating magnetic fieldcreated by the rotating magnet $\mathbf{2}$ is used to manipulate the attachment point of the arc $\mathbf{5}$ on the electrodes to provide extended electrode life and reduce maintenance costs. The plasma arc 7 serves as a resistive heating element with the electric current creating heat which creates additional plasma that allows the arc to be sustained. A major advantage of the plasma arc $\mathbf{7}$ as a resistive heating element is that it is formed in a gas and cannot melt or fail as can solid heating elements. Interaction between the arc and process gas $\mathbf{8}$ introduced into the torch causes the temperature of the gas to be very high and the hot gas $\mathbf{9}$ can exit the plasma torch at over $10,000^{\circ} \mathrm{C}$. The cooling water manifold $\mathbf{6}$ is provided to control the temperature of the torch body 1 .

The extremely intense energy produced by the torch is powerful enough to disintegrate the municipal solid waste MSW, or any hazardous waste into its component elements. Plasma torches are located near the bottom of the plasma furnace,Fig. 3, and direct the high temperature process gas into a bed of coke at the bottom of the vessel. Air or oxygen is introduced through tuyres located above the torches. The high temperature process gas introduced through the torch raises the temperature of the coke bed to a very high level to provide a heat reservoir to gasify the waste.

The subsequent reaction produces syngas and byproducts consisting of glass-like substances used as construction aggregates. Syngas is a mixture of hydrogen and carbon monoxide and it can be converted into fuel cells such as hydrogen, natural gas or ethanol. The hot Syngas so generated is fed into a heat recovery steam generator (HRSG) which generates steam. This steam is used to drive steam turbine which in turn produces electricity. The cooled gas is compressed and also used to drive a gas turbine to generate additional electricity - The integrated plasma gasification combine circle (IPGCC) can thus produce adequate electricity, part of which is used for plant load and the rest of the power generated is sold to the utility grid. Essentially the inorganic materials such as silica, soil, concrete, glass, gravel, including metals in the waste are vitrified and flow out the bottom of the reactor. There are no tars, furans or ashes enough to pollute the environment. The principal advantages of thermal plasma gasification processing as opposed to direct combustion (incineration) for the recovery of energy from wastes such as Municipal Solid Waste (MSW) include [1],[2],[10]:

- $\quad$ Production of a Syngas that can be combusted more efficiently than a solid fuel, resulting in decreased requirement for excess air while reducing the potential for formation of products of incomplete combustion (PICs). This results in a reduction of the volume of emissions and lower total emissions when treated to the same concentration standards. 
- $\quad$ Ability to clean the product gas prior to combustion, resulting in further reductions in emissions.

- $\quad$ Ability to utilize the Integrated Plasma Gasification Combined Cycle (IPGCC) process for generation of electricity which results in much higher thermal efficiencies (40-50\% energy recovery as opposed to 20-25 percent for mass burn facilities).

- $\quad$ The product gas can be transmitted by pipeline for use at locations at significant distances from the gasification facility.

Plasma gasification represents a clean and efficient option to convert various feed-stocks into energy in an environmentally responsible manner [1], [10]. Below are the environmental benefits of this process for power generation:Gasification occurs in an oxygen starved environment, so feed stocks are gasified, not incinerated. Due to high operating temperatures in the plasma gasification process [1]:

a) It produces no bottom ash or fly ash. b) Metals not recovered from the waste stream prior to processing and most metallic compounds are reduced to their elemental state and recovered in a form that permits recycling. c) Non-combustible inorganic materials such as glass, concrete, and soil are melted and vitrified, producing an environmentally stable glass-like residue that can be sold for use as construction aggregate. d) The high heat output from the plasma torches in combination with the heat reservoir provided by the coke bed at the bottom of the vessel permits the plasma gasifier to accommodate wide variations in feedstock composition and characteristics. e) The absence of moving parts in the gasifier in combination with the high temperature and flexibility of the plasma heating system makes it possible to process materials such as carpet and tires that are difficult to process in conventional incinerators or other gasification processes. f) The gasifier operates under a slight negative pressure, minimizing the potential for escape of the product gas. g) Continuous discharge of the molten residue through the coke bed at the bottom of the vessel eliminates the need to maintain a molten pool of residue in the vessel and associated problems with freezing of taps required for discharge of the residue. h) In general terms a thermal plasma gasification facility will have very low emissions of NOx, SOx, dioxins and furans.

\section{Materials And Mehods For Waste Treatment\&Power Generation}

\section{A. Wastes Treatment}

Thermal plasma technology is ideally suited to process wastes such as Municipal Solid Waste ("MSW"), common hazardous waste, industrial waste, chemical waste, military waste, low-level radioactive waste, medical waste, pathological wastes, $\mathrm{PCBs}$, sediment sludge and biomass. It can also vitrify fly ash from incinerators and any other types of ash. Converting waste into various energy outputs reduces reliance on the use of conventional fossil based fuels by using readily available wastes. In most developing countries such as Nigeria, wastes are commonly dumped in open dumps uncontrolled landfills where a waste collection service is organized. The dangers of open dumping are numerous; health hazard, pollution of ground water, spread of infectious diseases, highly toxic smoke from continuously smoldering fires, foul odors from decomposing refuse and emission of greenhouse methane gas. Several million tons of wastes have been deposited in open dumpsites across the countries over the years. A new technology involving Thermal Plasma Process applied to Gasification of MSW proves to be an environmentally friendly and sustainable solution for wastes treatment and power generation $[1,3,7]$.

\section{B. Plasma Gasification of MSW}

Plasma gasification is an efficient and environmentally responsible form of thermal treatment [11] of wastes which occurs in oxygen starved environment so that MSW is gasified, not incinerated. Westinghouse Plasma Corporation (WPC) has developed a plasma gasification system [12], [10],[13] which uses plasma heat in a vertical shaft cupola adopted from the foundry industry. The plasma gasification process is illustrated in Fig. 1 above. The power of plasma gasification makes it environmentally clean technique. Plasma Gasification Plant projects [14] are being developed by many gas plasma companies, such as Europlasma, with real benefits obtained from this technology.

As the waste moves downward through the "gasifying" vessel, inorganic materials such as metal, glass and soil are melted and produce a two phase liquid stream consisting of metals and a glass-like (vitrified) residue that flows to the bottom of the vessel. Discharge of the molten material into water results in the formation of metal nodules and a coarse sand-like material.

\section{Power Generation by IGCC}

The product syngas, after purification, can be passed through a conversion process to yield the desired high value products which include power, hydrogen, ethanol, diesel and petrol among others. Therefore, the conversion subsystem required will depend on the desired output product from the input syngas. The most desirable in developing economies is electric power, however, fuel cells are also important to reduce requirement for fossil based fuels. 


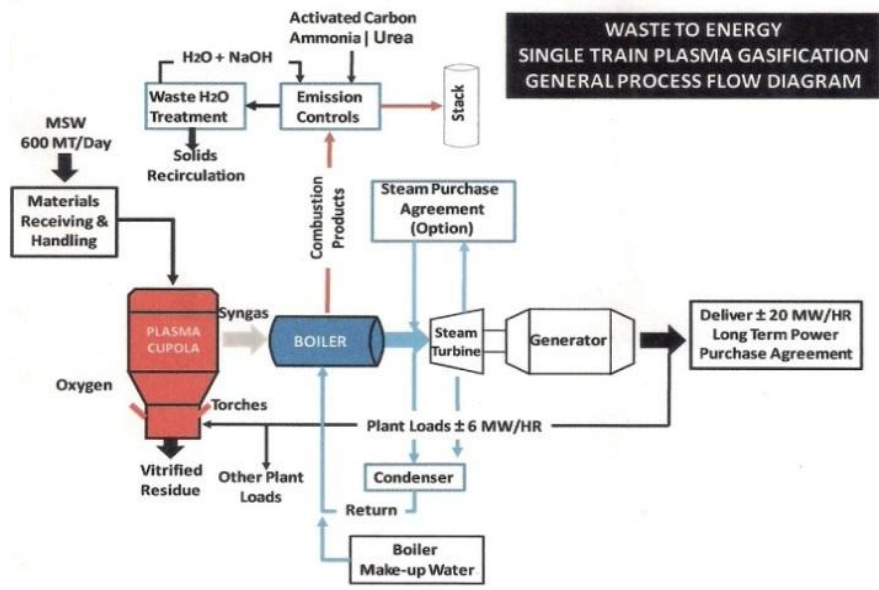

Fig.4. Gasification Plant Using Single Cycle Process

Fig.5 Typical 1000MT MSW plasma plant using IGCC for power generation TYPICAL 3,000 MT/DAY MSW PLASMA PLANT

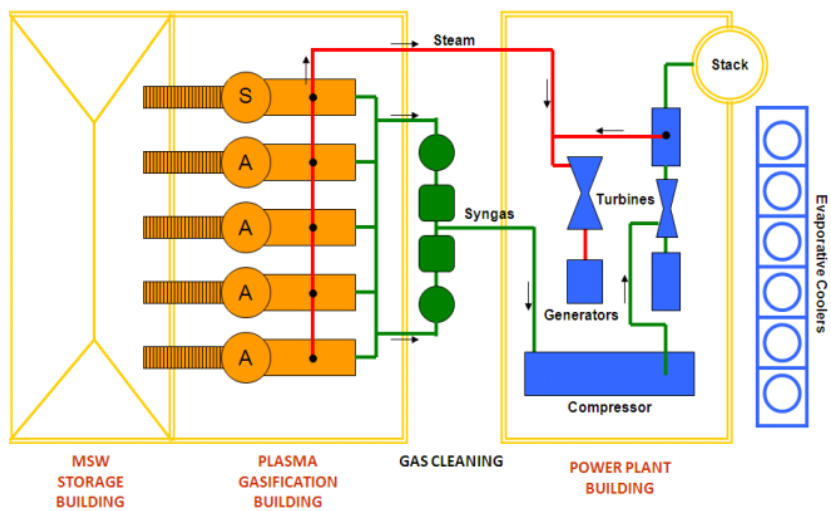

Figure 6: Plasma plant facility using IGCC for power generation

TYPICAL 1,000 MT/DAY MSW PLASMA PLANT

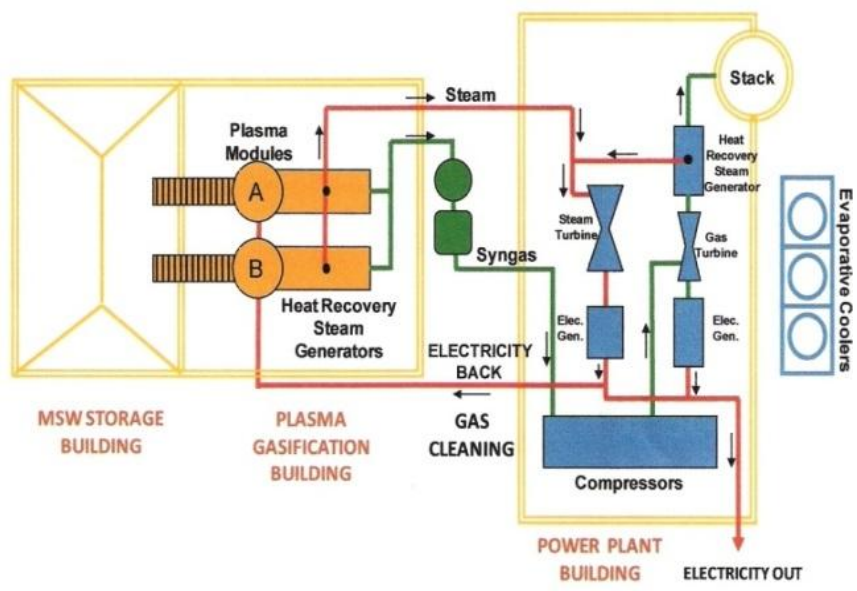

For electric power generation process, the product gas is cooled prior to clean-up by passing through a heat recovery steam generator (HRSG) and the recovered heat used to generate steam that is sent to the steam turbine to generate electric power by single cycle process (Fig.4.0). The cool gas is then cleaned using readily available technologies, compressed, and used as fuel in a combustion gas turbine driving an electric generator. The hot turbine exhaust gas passes through a second HRSG to produce additional steam prior to passing through a final emission control system designed to remove trace organics, metals and particulates prior to emission to the atmosphere. The steam from both HRSG units would be combined and used to produce additional electricity 
using a steam turbine generator (Fig.5.0). This is the process of integrated plasma gasification combined cycle power generation (IPGCC).

\section{Scalability of Thermal Plasma Power System}

One important advantage of a thermal plasma power plant is its scalability [4]. The ability to change the modules as the quantity of MSW changes, thereby, changing the power generation capacities. Fig.5.0 illustrates a 1000 MT per day Municipal Solid Waste capacity plant and demonstrates the relative ease by which plants can be expanded to meet increasing loadings through the use of standardized process modules with capacities of 500, 750 or 1000MT/day, see Fig. 6. A standby module, $\mathbf{B}$, is always included in the design to assure that processing capacity can be maintained during periods of scheduled maintenance. It should also be noted that a higher capacity could be achieved by adding standard modules to the $1000 \mathrm{MT} / \mathrm{day}$ facility. The ability to increase capacity by adding modular components as waste loading increases is obviously an important advantage to the thermal plasma gasification process for power generation.

\section{E. Efficiencies of Scale}

As with many industrial processes, increasing the size of the project increases efficiency. In the case of plasma gasification for power generation, these increases result from a combination of factors including proportionately smaller increases in internal plant loads on a per unit basis and increased efficiency of electrical generation through the use of larger units capable of operating at higher temperature and pressures that result in higher thermal efficiencies. The expected effects of increasing plant capacity on thermal efficiency and power output per ton of material processed are investigated and summarized in Table 1 below.

We notice from the table that for a combine circle power generation with plant capacity of 500MT/day, power generation is $26.7 \mathrm{MW}$ and the overall efficiency is $32.1 \%$. When the capacity is increased to $5000 \mathrm{MT} /$ day the overall efficiency increases to $38.9 \%$ and about $323 \mathrm{MW}$ of Electric power will be generated. This implies that the efficiency of the thermal plasma process for power generation increases with the increase in the plant capacity.

Table 1 Economies Of Scale In Combined Cycle Plasma Gasification

\begin{tabular}{|l|l|l|l|l|l|l|}
\hline $\begin{array}{l}\text { Input } \\
\text { Parameters }\end{array}$ & \multicolumn{5}{|l|}{ Combined Cycle (IGCC) Power } \\
\hline \hline $\begin{array}{l}\text { Plant } \\
\text { Capa } \\
\text { city } \\
\text { MT/d } \\
\text { ay }\end{array}$ & $\begin{array}{l}\text { Heat } \\
\text { Input } \\
\text { MWh } \\
\text { t }\end{array}$ & $\begin{array}{l}\text { Gross } \\
\text { Mwe }\end{array}$ & $\begin{array}{l}\text { Net } \\
\text { Mwe }\end{array}$ & $\begin{array}{l}\text { Plant } \\
\text { Load }\end{array}$ & $\begin{array}{l}\text { MWh/ } \\
\text { MT } \\
\text { MSW }\end{array}$ & $\begin{array}{l}\text { Overall } \\
\text { Efficien } \\
\text { cy \% }\end{array}$ \\
\hline $\mathbf{5 0 0}$ & $\mathbf{8 3 . 3}$ & $\mathbf{3 3 . 7}$ & $\mathbf{2 6 . 7}$ & $\mathbf{6 . 9 3}$ & $\mathbf{1 . 2 8}$ & $\mathbf{3 2 . 1}$ \\
\hline $\mathbf{2 5 0 0}$ & $\mathbf{4 1 6 . 4}$ & $\mathbf{1 8 6 . 9}$ & $\mathbf{1 5 2 . 1}$ & $\mathbf{3 4 . 7 6}$ & $\mathbf{1 . 4 6}$ & $\mathbf{3 6 . 5}$ \\
\hline $\mathbf{5 0 0 0}$ & $\mathbf{8 3 2 . 7}$ & $\mathbf{3 9 3 . 4}$ & $\mathbf{3 2 3 . 8}$ & $\mathbf{6 9 . 5 2}$ & $\mathbf{1 . 5 5}$ & $\mathbf{3 8 . 9}$ \\
\hline
\end{tabular}

\section{F. Environmental Sustainability of Plasma Gasification.}

Thermal Plasma process represents a clean and efficient solution to convert various feed stocks into energy in an environmentally responsible manner [3],[10]. In the plasma gasification process, heat nearly as hot as the sun's surface is used to break down the molecular structure of any carbon-containing materials - such as municipal solid waste (MSW), tires, hazardous waste, biomass, river sediment, coal and petroleum coke - and convert them into synthesis gas (product gas) that can be used to generate Electric power, liquid fuels or other sustainable sources of energy.

Burning or incineration does not occur in a plasma gasification unit, and so compared with other thermal conversion processes, gasification is completely different from incineration.Virtually any material, including low-level radioactive waste under certain conditions, can be reduced using plasma gasification. Materials that can be safely and effectively treated include coal, sludge, incinerator ash, hazardous fly ash, automobile shredder residue, medical waste, pathological wastes, PCB, oil pyrolysis products, ferrous chromium waste, ferro-manganese reduction compounds, titanium scrap melt, niobium recovery products, electric arc furnace dust, Portland cement manufacturing waste, paper, cardboard, plastics, fiberglass insulation and other products, asbestos, wood, glass, ceramics, rubber, tires, asphalt shingles, used roadway asphalt, oil sands, sewage sludge, harbor sludge, composite materials containing resins, linoleum, plastic piping, solvents, paints, and other carbon-containing materials including mixed solid waste [15].

The system will also handle such materials as steel beams and rebar; copper piping; steel, aluminum, and copper wire; and even concrete, stone, bricks, although it makes more sense from energy, environmental, and economic perspectives to remove such materials from the waste stream prior to processing [15], [16], [9]. 
Plasma gasification will also handle treated wood and even contaminated soils - both a problem currently for landfill and incineration operations.

\section{G. Waste Management and Power Generation - Environmental Consideration}

The rate of Carbon dioxide emission [17], [13] per MWH of electricity produced from different processes is very low for thermal plasma processing of MSW for power generation.

\section{Low Dioxin/Furan emissions: Fig.7}

- Less than $0.01 \mathrm{NG} / \mathrm{NM}^{3}$ of

Dioxins/Furans

- Sulfur reports as

Hydrogen Sulfide (H2S) easier to

clean than Sox

- Tars are cracked prior to leaving the Gasifier.

"One technology which potentially can use various types of waste, produce electricity and hydrogen without emitting dioxin, furan and mercury, is plasma arc technology.

Municipalities can install a plasma arc facility which will eliminate land filling ..." - EPA

\section{Carbon Dioxide Emissions:}

Plasma gasification WTE facility avoids:

1. The release of methane that otherwise would be emitted when trash decomposes in landfills

2. The displacement of $\mathrm{CO}_{2}$ that would have been emitted had the electricity been generated from fossil fuels such as coal.

This sophisticated waste destruction and electric power generating system operates on the principle of environment friendly waste destruction and sustainable generation of renewable energy.

In general terms a thermal plasma gasification facility has very low emissions of NOx, SOx, dioxins and furans and particulate matter.

There is an emerging global ([18], [19] consensus to develop local level solutions and community participation for better MSW management. Emphasis has been given to citizens' awareness and involvement for better [20] waste management.

\section{Comparison on Waste-to-Energy} Criteria Pollutants

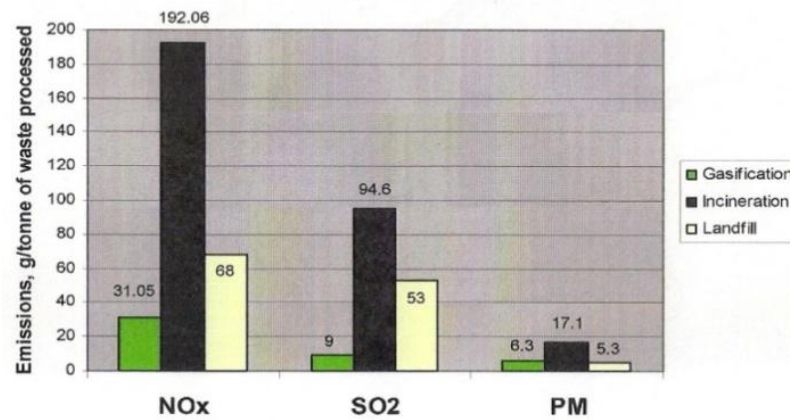

Figure7. Comparison of emissions on waste to power generation from Gasification, Incineration

A number of studies were carried out in the past to compare different methods of waste disposal and processing for different places. In the Netherlands [21],study concluded that composting was the best option of waste management. Study for the United Kingdom concluded that refused derived fuel [22] was the best option. In Nigeria, we have been pushing for thermal plasma solution for treatment of waste[2]. It can be inferred from the literature that no one method in isolation can solve the problem of waste management. The present paper aims to establish that thermal plasma solution for environmental waste management will not only lead to proper waste treatment but enhance alternative clean power generation.

The suitability of a particular technology for solving waste and power problems will depend on a number of factors which includes techno-economic viability, fuel availability, environmental factors, safety, sustainability [6],[23] and geophysical background of the location. Thermal Plasma Processes[4],[6],[7],[24], [13] seems to be a realistic solution for waste treatment and power generation. It is a disposal process that can 
get rid of almost any kind of waste by eliminating existing landfills, open dumps, and produce clean power for the national grid.

\section{H. Sustainability of Thermal Plasma Process}

The sustainability of any project will also depend up on the capital cost, running \& maintenance cost, availability of raw materials (feedstock for the plant) and return on investment. Capital costs for a plasma gasification plant are similar to those for a municipal solid waste incineration power plant, but plasma gasification plants are more economical because the plant's inorganic byproduct can be sold to the market as bricks and concrete aggregate. Plasma gasification plants also produce up to 50\% more electricity than other gasification technologies, [17] hence, reducing the payback period and increase return on investment. Nedcorp group plasma gasification system using Westinghouse Plasma Corporation plasma touches [4],[6],[10] uses 2 to $5 \%$ of energy input to produce $80 \%$ of energy output. Typical plasma gasification for waste to energy plant with a feedstock of 3,000 MT of MSW per day is estimated to cost over \$400 million for installation and will generate about $120 \mathrm{MW}$ of electricity [23]. Estimation for a 2,000 MT of MSW per day [25] is about $\$ 250$ million. Meanwhile estimation for 5000MT/day is about $\$ 600$ million and will generate about $400 \mathrm{MW}$ of electricity using IPGCC. It is also projected [19] that each ton of MSW has the potential to produce 900 $\mathrm{KWh}$ in single circle. The same plant can produce 1 to $3 \mathrm{MW}$ of electricity for each ton of MSW if it is equipped with cogeneration auxiliaries i.e. steam turbine and gas turbine [1],[4],[6] in an integrated plasma gasification combine circle (IPGCC). This implies that with larger capacities, the output power will increase and the cost will decrease significantly after the commencement of mass production.

\section{Results And Conclusion}

Environmental waste management problems and Power shortages in the world can be resolved by a thermal plasma solution for MSW treatment. The solution of these twin problems lies in Plasma Gasification of wastes. The Plasma Gasification Process of Municipal Solid Waste is a proven technology for waste to energy production [2], [6], [19]. The reaction processes in Plasma Gasification produce mainly syngas (Hydrogen and Carbon monoxide) [8]. The syngas is efficient in power generation using integrated plasma gasification combined circle (IPGCC) process. Operation is also shown to be environmentally responsible creating a product gas with very low quantities of NOx, SOx, PM, dioxins and furans. Inorganic components get converted to glassy slag safe for use and can be sold as construction aggregates and/or useful metal for recycling. The fuel gas emissions are also within prescribed limits [1],[2],[15], the process is environmentally safe in terms of rate of Carbon dioxide emission per MWH of electricity produced. The Plasma Gasification Processing plants will generate over $300 \mathrm{MW}$ of electricity when $5000 \mathrm{MT} /$ day is processed [1],[4] and this will be sold to the national grid.

Fast growing economies will find solutions to their problems [26] in waste management and energy productionusing IPGCC. Application of High-TechPlasma Gasification Process (HTPGP) [1] in waste to energy, relieves the pressure on distressed landfills, and offers an environmentally benign method [2],[24] of disposing MSW, much better than other gasification processes[1],[3],[4]. Municipal solid waste is considered as a source of renewable energy, and thermal plasma process is one of the leading-edge technologies available to harness this energy, and qualifies for carbon credit. Recently, the US government officially declared the MSW as a renewable source of energy, and power generated through the use of MSW is considered green power and qualifies for all eligible incentives. Thermal Plasma gasification is an economic and sustainable source of green energy, and a reliable source of power generation in integrated plasma gasification combined cycle (IPGCC). There are many applications of thermal Plasma Gasification Process and the profit potential of plasma conversion [2],[4], [25] is tremendous.

The Thermal plasma process applied to treatment of MSW has all the merits of adoption for waste management and power generation, developing countries are encouraged to sponsor more research in this area especially to reduce costs and further improve efficiency. There is, however, consensus that alternative sources of energy and power that are sustainable, environmentally friendly and regionallyavailable is the best choice for the future. We conclude that thermal plasma processes applied to gasification for waste treatment and power generation is viable, sustainable, environmentally-friendly and is the future of green power generation.

\section{Acknowledgement}

I am grateful to the Vice Chancellorand Management of the Federal University, Ndufu-alike-Ikwo (FUNAI) for the encouragementand support through the approved academic research leave which facilitated this work. 


\section{References}

[1]. Anyaegbunam F.N.C. (2013), A New Method of Power Generation by Plasma Physics. International Journal of Engineering Research \& Technology (IJERT), Vol. 2 Issue 8, August - $2013 \mathrm{PP}_{2428-2437}$

[2]. Anyaegbunam F.N.C. (2013), Sustainable Power Generation by Plasma Physics, American Journal of Engineering Research (AJER). Volume-02, Issue-08, $\mathrm{pp}_{65-75}$.

[3]. Anyaegbunam F.N.C. (2013), Environmentally Friendly and Sustainable Municipal Solid waste Management in Abuja. International Journal of Engineering Science Invention. Volume 2 Issue 7, July. 2013. PP $_{42-50}$

[4]. Anyaegbunam F.N.C. (2013),Plasma Gasification for waste management and sustainable renewable clean energy generation. In the Proceedings of Nigerian Academy of Science (PNAS), 2013.

[5]. Langmuir I. (1928), Oscillations in ionized gases, Proceeding of National academy of science, U.S. $14(8)$, pp 628.

[6]. Chen, Francis F. (1984), Plasma Physics and Controlled Fusion. Plenum Press. ISBN 0306413329

[7]. F.N.C. Anyaegbunam(2013), Invention of Waste Destruction and Power Generation (WDPG) Plasma System for Nigeria Patent (2013).

[8]. YoungchulByun, Moohyun Cho, Soon-Mo Hwang and Jaewoo Chung, (2012) Thermal Plasma Gasification of Municipal Solid Waste (MSW). (www.intechopen.com thermal plasma_gasification of municipal_solid_waste)

[9]. Dodge, E. (2009) Plasma Gasification: Clean Renewable Fuel Through Vaporization of Waste. Emerson Process Management.WaterWorld. (http://www.waterworld.com/index/display/articledisplay/368649/articles/wastemanagementworld/volume-10/issue-4/features/plasma-gasification-cleanrenewable-fuelthrough-vaporization-of-waste.html

[10]. Nedcorp Group (2009) Environmentally Friendly Waste Destruction and Sustainable Renewable Energy. A feasibility document of Nedcorp group, July 2009.

[11]. Evans Steve D, (2009), Plasma Gasification Plant Benefits for Municipal Waste Management, EzineArticles.com, available at http://www.articlesbase.com/literaturearticles/plasma-gasification-plant-benefits-for-municipal-waste-management- 850915 html, accessed during December 2011

[12]. Patel MunnaLal, ChauhanJanardan Singh (2012), Plasma Gasification: A Sustainable Solution for the Municipal Solid Waste Management in the State of Madhya Pradesh, India. INTERNATIONAL JOURNAL OF ENVIRONMENTAL SCIENCES Volume 3, No 1, 2012

[13]. Anyaegbunam F.N.C., (2013), Plasma gasification and sustainable renewable energy in Nigeria. International Journal of Environmental Science and Technology, July 2013.

[14]. Dighe, Shyam V. (2008), Westinghouse Plasma Corporation, Madison, Pennsylvania, USA, Plasma Gassification : a proven technology, Proceedings of NAWTEC16, 16th Annual North American Waste-to-Energy Conference, May 19-21, 2008, Philadelphia, Pennsylvania, USA.

[15]. DOVETAIL PARTNERS, INC. ( 2010) Plasma Gasification: An examination of the Health, Safety, and Environmental Records of Established Facilities Prepared for the City of PALISADE, MINNESOTA June 7, 2010

[16]. Thomas, R. (2007).Ability of Plasma Gasification to Handle Construction and Demolition Waste. (http://www.bape.gouv.qc.ca/sections/mandats/LET-danford-lake/documents/DM58-3.pdf) 16

[17]. Circeo L. J, (2012), Plasma Arc Gasification of Municipal Solid Waste. Georgia Tech Research Institute, Environmental Science and Technology Program, Electro-Optical Systems laboratory.

[18]. RathiSarika, (2007), Optimization model for integrated municipal solid waste management in Mumbai, India, Environment and Development Economics 12, pp 105-121.

[19]. Pourali, M., (2010), Application of Plasma Gasification Technology in Waste to Energy-Challenges and Opportunities, The IEEE Xplore digital library (Institute of Electrical and Electronics Engineers), 1(3), pp 125-130,

[20]. Beukering, (1999), Waste recovery in Bombay: a socio-economic and environmental assessment of different waste management options, Third World Planning Review 19(2),pp 163-187.

[21]. Maimone, M., (1985), An application of multi-criteria evaluation in assessing MSW treatment and disposal systems, Waste Management and Research, 3, pp 217-231.

[22]. Powell, J.C., (1996), The evaluation of waste management options, Waste Management and Research 14, pp 515-526, reprinted in Powell et al. 2001

[23]. Varma, R. Ajayakumar, (2009),Technoligical Options for Treatment of Municipal Solid Waste with special reference to Kerala, Workshop on Public Office Sanitation at State Municipal House on 25th Sept 2009, available at sanitation.kerala.gov.in/pdf/workshop/techno_2.pdf, accessed during December 2011.

[24]. Lisa Zyga, (2012), Plasma Gasification Transforms Garbage into Clean Energy, Science Blogger, InventorSpot.com, via: Popular Science.

[25]. Blees Tom, (2008), Prescription for the Planet, The Painless Remedy for our Energy \& Environmental Crises, ISBN: 1-4196-55825, ISBN-13: 9781419655821 Library of Congress Control Number: 2008905155.

[26]. Henry, (2006), Country report, Municipal solid waste management challenges in developing countries - Kenyan case study, Waste Management, 26, 92-100. 